\title{
Distressed Debt Management \& Lessons Learnt Through Case Management: Banking Industry in Kenya
}

\author{
Robert Githua Muriithi
}

\section{ABSTRACT}

Deteriorating and troubled assets must be subjected to enhanced risk oversight and monitoring to ensure that appropriate action is taken in a timely manner, allowing a high level of obligor turnaround success and reduced risk of loss for the Lender/Financial Institution/Bank. It's important for a Bank to harmonize Distressed Debt Management approach, called the Watch List (WL) Framework, and details the requirements to ensure timely adherence to regulatory requirements. The impairment requirements of International Financial Reporting Standards (IFRS 9) Financial Instruments, effective as of 1 January 2018, are based on an Excepted Credit Loss (ECL) model and replace the IAS 39 Financial Instruments; Recognition and Measurement incurred loss model. IFRS 9, recognizes impairment allowances on either a 12-month or lifetime ECL basis, dependent on whether there was a significant increase in credit risk (SICR) since initial recognition (being either asset origination date or 'base date', whichever is most recent). The measurement of ECL reflects both a probability-weighted outcome and the time value of money, using the best available forward-looking information. There should be relevant policies that would require to be read in conjunction with relevant manuals and Accounting Standards. It's equally important to detail the monitoring objectives for consistent management of wholesale impairment and the provisions necessary to meet regulatory requirements. It is imperative that when dealing with Distressed Debt/Assets, that attention is given to the requirements detailed under Conduct Risk and that client confidentiality is maintained. Mostly, business failure is a result of financial and/or economic distress. A firm in financial distress experiences a shortfall in cash flow needed to meet its debt obligations. Its business model does not necessarily have fundamental problems and its products are often attractive. In contrast, firms in economic distress have unsustainable business models and will not be viable without asset restructuring. In practice, many distressed firms suffer from a combination of the two. Many factors contribute to the high number of business failures. Some common failures include and are not limited to the below. Poor operating performance and high financial leverage. A firm's poor operating performance may result from many factors, such as poorly executed acquisitions, competition, overcapacity, new channels of competition within an industry (e.g., retail), commodity price shocks (e.g., energy), and cyclical industries (e.g., airlines). High financial leverage exacerbates the effect of poor operating performance on the likelihood of corporate failure. Lack of technological innovation. Technological innovation creates negative shocks to businesses that do not innovate. The arrival of a new technology often threatens the survival of firms that possess related, yet less competitive, technologies. There needs for a business to strategically position itself in the market through digital transformation in its processes, product development and operations Liquidity and funding shock. In periods of weak credit supply, some businesses are unable to roll over maturing debt because of illiquidity in credit markets. Relatively high new business formation rates in certain periods. New business formation is usually based on optimism about the future. But new businesses fail with far greater frequency than do more seasoned entities, and the failure rate can be expected to increase in the years immediately following a surge in new business activity. Deregulation of key industries. Deregulation removes the protective cover of a regulated industry (e.g., airlines, financial services, HealthCare, energy) and fosters larger numbers of entering and exiting firms. Competition is far greater in a deregulated environment. Unexpected liabilities. Businesses may fail because off-balance sheet contingent liabilities suddenly become material on-balance sheet liabilities.
Submitted : January 05, 2022

Published : January 28, 2022

ISSN: 2507-1076

DOI: $10.24018 /$ ejbmr.2022.7.1.1252

\section{R. G. Muriithi}

BSC, MBA, London Institute of Banking \& Finance, Jomo Kenyatta University of Agriculture \& Technology, Kenya.

Credit Risk Advisory | Business Turn Around | Debt Restructure \& Recovery |

(e-mail: rmgithua@gmail.com) 


\section{INTRODUCTION}

By definition, distressed debt is deteriorating and or troubled assets which must be subjected to enhanced risk oversight and monitoring to ensure that appropriate action is taken in a timely manner, allowing a high level of obligor turnaround success and reduced risk of loss for the Bank through a program referred to as distressed debt management. This is normally done through Credit Risk Management under various names given by different lenders/banks or financial institutions; Problem Loan Management, Business Support \& Corporate Recoveries/Resolution, Credit Risk and Restructuring Advisory, Special/Troubled Asset Management and Debt Remedial, etc.

This is an area of focus by lenders and especially due to the impact of Covid-19 where businesses have been adversely affected leading to failure or total collapse hence increasing the impairment risk and credit loss to lenders.

This has over a period of time been tested and proven to be a prudent way of mitigating credit loss and impairment risk. Banks/lenders are in the business of lending money which is a risky affair and definitely are profit making and have a responsibility of making a return to the shareholders. No one lends money to lose it and hence measures are put in place to reduce the probability of loss and banks are not exempt.

Proper distressed debt management increases trust, offers support to businesses that would have otherwise collapsed and in the long run affect the livelihood of the entire ecosystem whose survival is dependent on those businesses. This is an area that any responsible lender should priorities and employ in their Risk Management and Lending Framework. The good far much outweighs the bad and as a matter of fact, banks are not in the business of selling securities, they are in the business of lending money.

The very first thing that any prudent lender is supposed to do upon identification of any flags is to check on security documentation and immediately remediate any security defects.

\section{OBJECTIVE}

- To Demystify Distressed Debt Management.

- To Provide Some Lessons Learnt.

\section{DISTRESSED BUSINESSES}

\section{A. Identification of Distressed Businesses}

\section{1) Control, Requirements}

Credit Deterioration obligors believed to be facing financial difficulties or where there are grounds for concern regarding their financial health are identified at an early stage. This allows corrective action to be taken to ensure successful turn around and reduced risk of credit loss.

Financial Difficulties are deemed to have arisen where there has been, or it can reasonably be foreseen there is likely to be a material weakening in an obligor's ability to meet its obligations to the bank. Deterioration in financial strength results in downward movement in obligor's grade and may also lead to the obligor entering watch list classification for closer monitoring.
The first line of defense and second line of defense identify deteriorating financial strength. This is a subjective qualitative and quantitative assessment but can be evidenced by one or more of the following indicators which may trigger watch list classification. The indicators can either be evidence from a Credit Analysis, Exposure Analysis / Obligor Financial Behavior or Arrears as outlined below.

2) Credit Analysis

- High/huge and aging Debtor /Creditor book;

- Deterioration in Profit and Loss performance;

- Doubt over historic financial performance resulting from:

* Financial reporting improprieties (actual or alleged); * Change in auditors other than for logistical reasons;

* Downwards restatement of earnings;

* Regulatory investigations or;

* Other similar events raise questions over the accuracy of historic performance.

- Significant and sustained drop in the share price of publicly traded company due to microeconomics factors;

- Significant and sustained drop in the debt price of company due to microeconomic factors;

- Net tangible assets declining in circumstances that are not adequately explained;

- Declining financial ratio coverage;

- Material reduction in collateral valuation;

- Additional borrowing, leasing, invoice discounting or similar facilities taken through other lenders;

- Unexpected senior management changes.

Exposure Analysis/Facility Behavior

- Unusual or unexpected drawdown of facilities, short term (no more than 10 days) in receipt of payments;

- Covenant waiver requests or breaches, delays in receipt of compliance certificates or iterative weakening of the terms of the credit agreement;

- Where an excess has not been rectified within the banks acceptable timeframe and / or there is evidence of reoccurrence of excess and remediation activity have been exhausted;

- Exposure is high in absolute terms or relative to other lenders exposure.

We could further categorize the indicators under Business, Management, Debt and Financials as below. There could be many other ways of categorizing e.g., external and internal but will choose to use the below model that one can consider while down-streaming an account for distressed debt management. The list may not be exhaustive. 
TABLE I: INDICATORS-DISTRESSED BUSINESS

\begin{tabular}{|c|c|}
\hline Business & Management \\
\hline 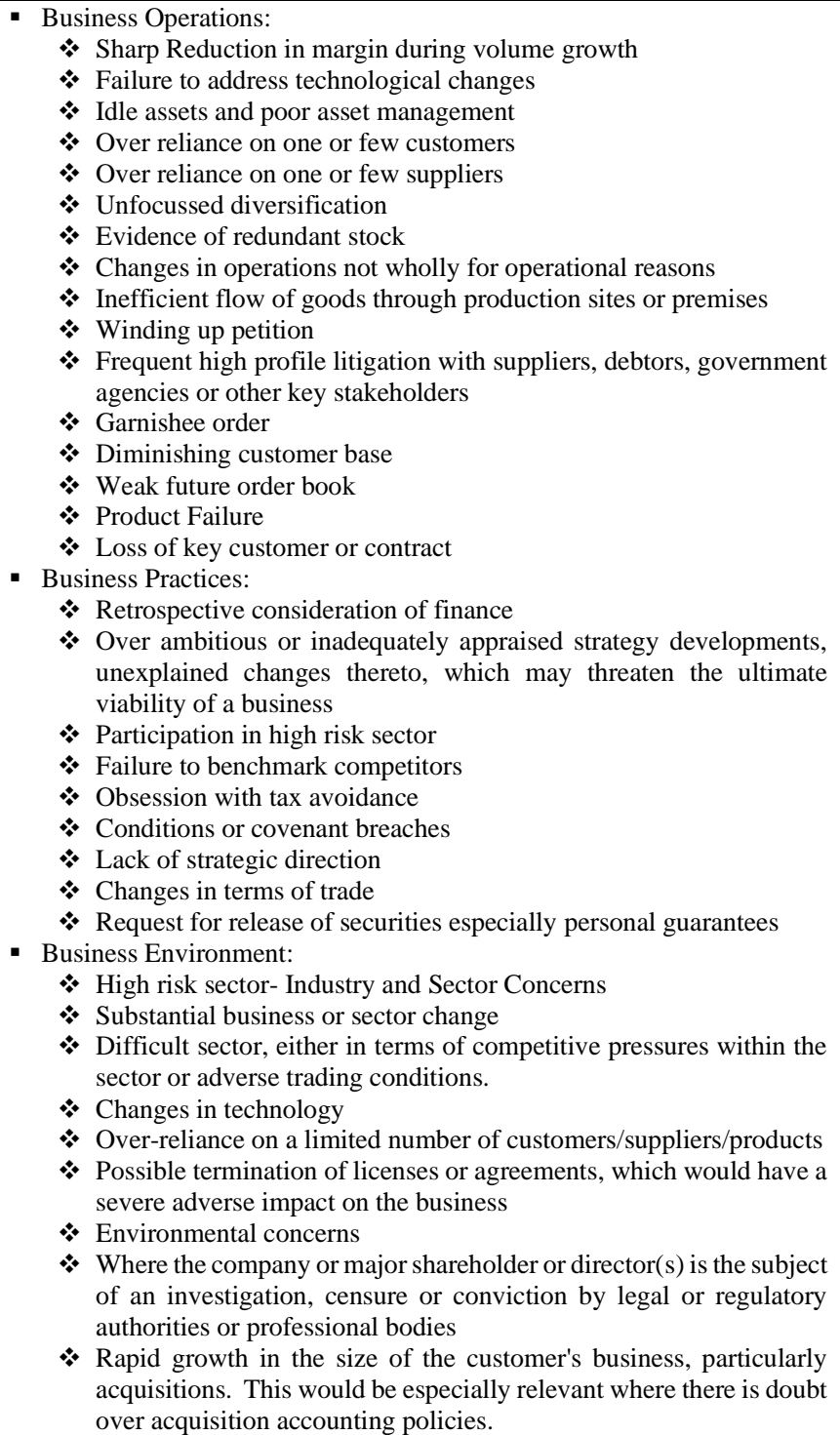 & $\begin{array}{l}\text { Unexpected Senior Management \& Share Holders changes. } \\
\text { Elusive or delaying directors } \\
\text { Change in attitude after several meetings with the bank/lender } \\
\text { Lack of business sector knowledge } \\
\text { Reactive management } \\
\text { Management team not developing as the business expands } \\
\text { planning family owned business, family feuds or succession } \\
\text { High senior and middle management and general staff turn } \\
\text { over } \\
\text { - Inplanned management changes } \\
\text { Imbalance in management-over dominant Managing } \\
\text { directors/Senior managers. Poor quality of non-executive } \\
\text { directors (especially the independent ones). These raises } \\
\text { questions on whether the other directors understand the } \\
\text { financial information and whether the financial directors } \\
\text { communicate with the other directors } \\
\text { * Ineffective strategies and no close monitoring } \\
\text { Lending Fraud/Diversion * turnover/ facility proceeds, } \\
\text { Weak management /ownership( Skill/financial/quality of } \\
\text { auditors/theft) v-s growing businesses } \\
\text { Lack of Proper governance structures }\end{array}$ \\
\hline Debt & $\begin{array}{l}\text { Financials } \\
\end{array}$ \\
\hline $\begin{array}{l}\text { - Unexpected or unplanned increased borrowings } \\
\text { - Unsatisfactory Bank account conduct } \\
\text { - Excesses } \\
\text { - Covenant breaches or waiver / reset requests } \\
\text { - Payment deferral requests } \\
\text { - Restructuring requests } \\
\text { - Cross Firing / Fraud/Cheque Kitting } \\
\text { - Unusual or unexpected drawdown of facilities, short term (no more than } \\
\text { - Covens) in receipt of payments } \\
\text { - } \text { certificates or iterative weakening of the terms of the credit agreement } \\
\text { - Exposure is high in absolute terms or relative to other lenders exposure } \\
\text { - Additional borrowing, leasing, invoice discounting or similar facilities } \\
\text { - } \text { Oven through other lenders } \\
\text { - Exposure to Government deals( National/County) } \\
\text { - Diversion of funds into non-core business activities } \\
\text { - Reliance on a large overdraft, despite being profitable. This is a symptom } \\
\text { - } \text { of over trading } \\
\text { - Institutions with or without prior consent or knowledge of the Bank } \\
\text { - Rising hardcore }\end{array}$ & 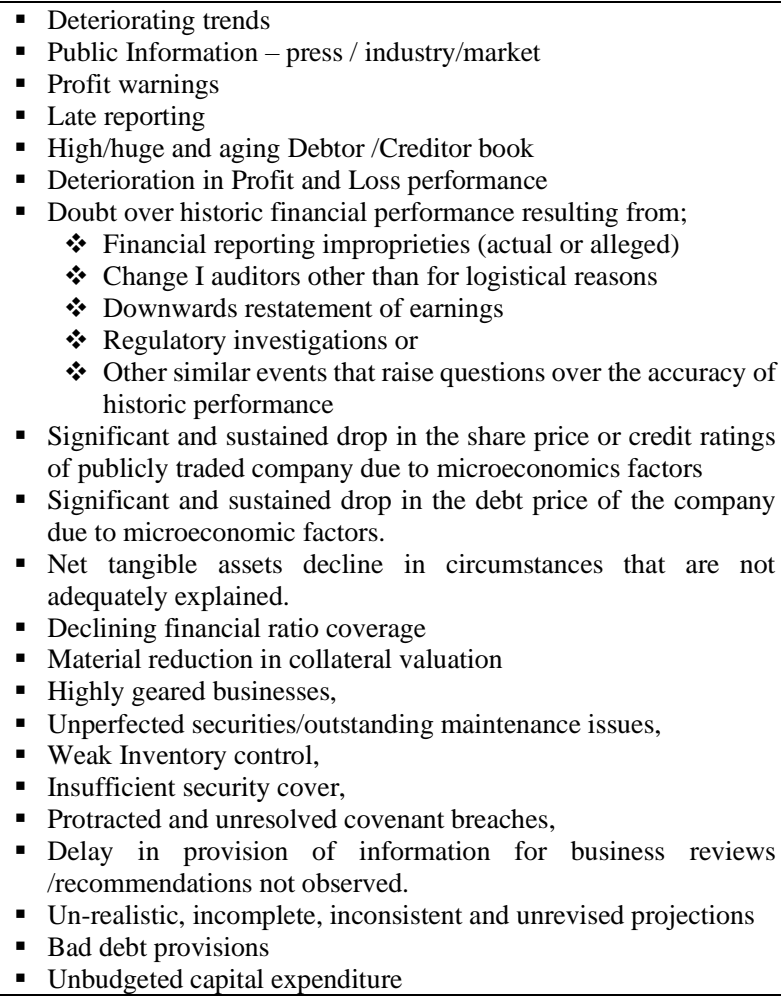 \\
\hline
\end{tabular}


- Significant variance from forecasts

- Inappropriate accounting policies, particularly in recognition of income and profits

- Window dressing

- Increased overheads in relation to turnover

- Increasing use of other debt funding instruments

- Sudden requirement to use alternative suppliers

- Failure to control working capital, particularly in relation to stock levels

- Small or diminishing margin of safety

- Adverse trends in credit turnover

- Unmet statutory deductions/payments

- Difficulty meeting obligations

- Cash outflows

- Reduction in order book or other leading indicators

- Increased reliance on creditors

- Adverse debtor age spread or trends

- Late audited/management accounts

- High goodwill or intangible elements in the balance sheet

- Reducing turnover (debit or credit)

- Covenant breaches (on primary or other facilities)

- Failure to meet interest or loan repayments

- Adverse security revaluation

- Excesses (unadvised)

- Eroding debenture cover

- Return of cheque

- Where there has been a substantial increase in exposure over a short period, particularly in relation to total credit lines

There are several circumstances that would require mandatory referral to Distressed Debt Management regardless of Watch List categorization some of which are below:

* Cross-firing / Fraud

* Business Reviews - a review of the business, due to under performance, by accountants or consultants acting for the customers, creditors, or bank.

* Failure to settle a derivative trade within 30 days of the due date.

* Failure to meet loan repayments within 14 days of due date-(triggered by Unique event(s) leading to increased credit risk else should be managed by relationship under Watch List 1).

* Restructuring requests which including hard-core overdraft term outs, any roll up / capitalization of interest or capital repayments or any capital or interest holiday periods.

* Profit Warnings.

* Material Covenant Waivers/Breaches.

* Deferral of repayments - a request to defer loan repayment/or agreed overdraft reductions.

\section{B. Early Warning Questionnaire}

The first line of defense (FLOD) through watch list committees can use the below early warning questionnaire template which can act as a guideline for early risk identification to address the risk before it crystallizes and address the route course. Time is of the essence, hence the earlier risk is identified the easier it is to address it to prevent further deterioration which can result in a name being downgraded from live/normal/regular book all the way to recovery/liquidation scenarios.

For the names that have started showing signs of struggling, the below developed questionnaire can be of help in narrowing down for decision making. It needs completion and explanation provided for each. In the event of any of the below, further referral, interrogation and escalation may be required.
* Have there been unauthorized excesses in the last 3 months?

* Have any cheques been returned unpaid?

* Is there evidence of a weakening balance sheet? Deteriorating NTAs.

* Are there breaches in monitoring and control of the facilities?

* Has there been any key change in personnel and ownership?

* Has there been adverse publicity? Strike action, customer boycotts, regulatory legal actions, etc.

* Have there been frequent requests, more than 2 in the last 6 months?

* Have there been significant changes in the account conduct over the last 6 months e.g., hardcore, declining turnover, etc.

* Are profit margins being eroded?

* Has the company been attempting to raise finance elsewhere?

* Has there been a substantial, more than $10 \%$ decline in the value of securities?

* Have any securities remained unperfected over a period of 3 months?

* Have there been requests to release securities over the last 3 months?

* Has the review of facilities been delayed for more than 3 months?

* Have there been delays in the provision of agreed figures?

* If budgets/cash flows are being monitored, is there more than $10 \%$ variance from forecast figures?

* Have any key suppliers/customers (more than $10 \%$ of income/purchases) or associated companies (common ownership) defaulted, experienced a credit event or been party to adverse publicity in the last 3 months?

* Has the company been affected by a recent exchange rate movement or changes in local legislation/regulation? E.g. Net importer hit by significant depreciation in local currency or new 
restrictions imposed by the government that adversely affect a customer's ability to trade.

* Has the counterparty risk profile deteriorated by more than two notches in the last 12 months?

* Is there an unexpected material (more than 10\%) difference between the customer's audited and management accounts? Unexpected/Unadvised change of auditors?

* Is the customer's financial performance significantly misaligned with perceived industry norms? E.g. financial ratios out of sync with industry average especially how much stronger performance with no sound explanation why. If so, Yes to be ticked unless there is a credible explanation.

* Have funds been drawn outside of the conditions of approval or has the customer sought to draw funds for purposes other than those originally agreed by the bank?

* Have any red flags been recognized during a visit? E.g. fully stocked warehouse at the end of customer's accounting cycle.

* Has the customer declined/avoided meeting bank officials or shown unwillingness to respond/comply with bank requests/enquiries?

* Have other concerns been raised relating to potential fraud?

\section{Detailed Review}

Review file to confirm that the documentation held is complete. This will include security review with internal/External legal personnel's to confirm completeness $\&$ enforceability. Any security defects must be remediated as a matter of priority. By engaging the client via visits, it is important to perform a deep dive analysis of the business to ascertain its viability. There are simple steps that one can take to determine the way forward in a case of distressed debt management; after through deep dive into the business which is not limited to the below.

Areas of Detailed Review:

* Business Status

* Management

* Business Operations

* Business Practices

* Business Environment

* Current facilities and performance

* Account Conduct-Overall, primary plus other banks

* Trading performance

* Business Plan, Budgets and Forecasts

* Security Details Analysis

* Impairment Analysis-Understanding Bank Risk on provisions

* Understanding the fundamental drivers of concerns

* Business risk analysis

* Cash generation and use analysis

* Management assessment/Competence

* Viability of the business

* Key Options to the bank \& Recommendations for the way forward

The following are some of the key considerations when weighing the options:

* What is the objective? Should you support the distressed customer or not
What options do the bank and the customer have?

* Who the stakeholders are and what their plan is

* How do you minimize risk of ultimate default and increased potential for provisions?

* How should you generate and protect bank's income/interest.

* Do you need to use turnaround professionals?

* Is this a case of Recovery/Insolvency?

* Use of appropriate strategy sheets/forms

\section{Strategy Formulation/Setting}

Formulate a strategy way forward which needs to be agreed upon with the former relationship and all other stakeholders aligned. This is very paramount as it will determine the success of the strategy. The manager of the distressed asset will also require the support of the former relationship and leverage on the rapport built over time to unlock any hurdles. The strategy formulated is informed by the outcome of the review. This may take 1-3 months dependent on information availability and the complex nature of the case. Some of the strategies include:

* Business Turn-Around;

* Debt Reduction;

* Managed Exit through Debt Take-Over/Re-banking.

Determine next steps: this is dependent on the strategy formulated. This requires that the business marries the customer's strategy and the lenders/bank's strategy to realize win-win compromises/situations. This is even made easier when the customer is on top of his game and the same is cooperating such that there are clear agreed upon action points by the bank and customer with clear timelines.

* A clear and appropriate strategy and action plan.

* A reasoned, balanced and objective understanding of business risks.

* Appropriate Monitoring \& Control activity (i.e. the right things at the right frequency)

* Appropriate involvement of third-party professionals.

* Correct recognition of Bank risk, including appropriate commentary on value of property and other assets held as security.

* Where Bank risk exists, evidence of appropriate action to mitigate

* Use of optimum facility structures.

* Minimization of Severity as far as possible given security available.

* Operate to the principle of 'zero tolerance' of excesses.

* Active management of payment arrears.

Turnaround strategy may take some time and is also dependent on the complex nature of the case which is tied to business viability.

When setting strategy a business review may be deemed necessary to establish a sound basis on which to negotiate and move forward. This requires careful evaluation by independent, trusted business advisory professionals to execute either a turnaround strategy or offer corporate insolvency services with the aim of recovering value for the various financial stakeholders in the business.

Cases from Problem/Distressed/Troubled Loan Management may be closed in 3 circumstances:

* Cases are returned to branch control where those risks/warning signs, originally identified as a concern, 
are minimized enabling removal from the Early Warning List.

* Managed exit achieved through repayment or rebanking and no desire to continue the relationship with customer. Account to be closed.

* Customers' problems worsened and recovery procedures considered appropriate, move account to Corporate Recoveries Team.

\section{E. Turnaround}

When deciding that the objectives is to turn-around the business, the aim will be to improve the credit risk profile of the bank's customer to its satisfaction and then provide a continuing healthy relationship with the customer. The Bank would wish to retain the business and therefore calls for investing in the customer through building the relationship with either the existing or new management and possibly consider additional funding. In setting out the strategy, it is important to remember that within it there are often two key stages;

- to create financial stability and

- take any further necessary action to help place customer back on track.

It is important to note that the turnaround of these cases can take between 18-24 months depending on the complexity of the case and/or number of lenders involved.

\section{F. Managed Exit}

The objective of a Managed Exit should be to deliver a relationship exit for both the Bank and the customer which aims to avoid or minimize loss. Within this strategy, we first stabilize finances and then divest, avoiding customer default but achieving a reduction in, or repayment of, exposure and/or an improvement in the bank's secured position.

If the problems in the business are found to be fundamental and therefore cannot be resolved, then early identification presents the Bank with a better opportunity to manage the exit of the customer, e.g. through refinance by a competitor. This is because these problems may have yet to become apparent to a significant level, at least in the records of the business performance.

\section{G. Strategies to Achieve These Objectives}

Once the objectives of either turnaround or managed exit have been agreed upon, it is necessary to adopt these strategies required to achieve the objectives. These strategies will flow from customer analysis, what is required to stabilize the business and the profitability of success of management to redirect the business. Such strategies include

- Professional assistance to be provided to the customer

- Business restructuring to be undertaken by the customer

- Strengthening management of the business

- Improve banks security position

- Reduction in bank debt/improvement in gearing

- Improvement of financial control

\section{H. Implementation}

In the implementation, the following will need to be considered:

- Is the plan defined with milestones, timed and owned?

- What are the key issues, dependencies and risks?

- Is there rigor in monitoring?
- Is the plan achieving the objective?

- Is there new information to analyze and action?

- Review of the progress against the plan

Actions which will be required to achieve the objective will involve but are not limited to the below:

- Obtain an Independent Business review to understand fully the current situation and help develop attainable solutions

- Obtain regular and reliable financial information in order that an up to date understanding of financial position can be achieved

- Obtain capital injection

- Have oversight of the financial aspects/account conduct

- Establish Oversight of the financial aspects/account conduct

- Establish a repayment program

- Ensure sale of property by a specific date

Influencing customers to change and implement corrective strategies is often difficult and handling such troubling situations is challenging. It is therefore important that all strategies and actions adopted to achieve the objective are clearly recorded on the strategy sheet with milestones for regular review and compliance confirmations.

\section{Restructure/Additional Funding}

When looking at cases gone wrong, you need to ask whether you (the bank) are willing to put in "good money after bad". Such reflects a situation where a loss has been caused or increased by further lending when in fact a business was already facing difficulties.

A request within a period of approval for increased facilities might be the result of a customer's forecasts being exceeded with a consequent requirement for more working capital of capital expenditure. The lender may be willing to consider such requests.

However, the main problem arises where extra borrowing is required to cover customer's failure to live up to their plans. The original plan should have some margin of error built into the assumptions and any request for increased facilities is likely to be unwelcome. When should the Bank be prepared to lend more and when should the request be declined? It would be necessary that the following factors are taken into account;

- Management-By definition, there would have been failure by management to predict and plan adequately. The counter argument to expect would be that the management will improve future performance. It is therefore important that a detailed analysis of management is undertaken to enable the Bank to arrive at an informed decision. Management's integrity must also be considered. Have they been honest with the Bank? Have they used the facility for the purpose it was intended? Might they have been aware of significant downside risk at the outset but hid it from the bank? If the management cannot be trusted, it is recommended not to lend any more.

- Underlying assumptions-The business's performance will have provided a test for the assumption which were the foundation of its plans. Have these worked out in practice? If major assumptions have been found to be incorrect, is the plan still viable? Have the assumptions 
in any new plan been sufficiently revised or do they still look optimistic?

- Trends-Insist on seeing the sufficiently detailed information on performance to date to be able to judge the direction in which the key elements of the business are moving. If indications are that the performance is flat rather than improving then this must be reflected in the new forecasts. It is necessary to be particularly skeptical if the updated projections assume that matters are getting better but there is no concrete evidence of this.

- Security margin-If the security margin was just adequate when the original lending was done, it is unlikely that it will be desirable to see it eroded on the back of the failure to perform. Should the Bank decide to provide additional financing, the customer will be required to provide additional security. However, care should be taken not to lend more simply to obtain poor quality security to cover a perceived risk situation.

- Risk-lending more against reduced net assets or a fixed level of security will generally involve or result in taking higher risk. Make an assessment of the probable loss if the Bank does lend more and compare this with the worst case scenario say in six months' time if the customer requests are met and performance continues to deteriorate. Is the extra risk worth it? You should be reminded that the Bank does not do the customer any favor by allowing him to incur more debt in pursuit of forlorn hope.

Where further facilities are granted to a customer, known to be in difficulties, pending reductions from specific sources, care must be taken;

- To verify and possibly legally and transactionally secure that the reductions will indeed be forthcoming and will be applied as arranged.

- To ensure that the funds cannot be diverted from the Bank even if the borrower has been bankrupt or placed under liquidation in the meantime.

- Where additional security is required as a condition of approval for the new facility this must be perfected before drawdown, of the additional or restructured facilities.

- In circumstances where drawdown is requested before perfection a specific and formal confirmation from Bank lawyers that perfection can proceed without customer's involvement will be required.

\section{J. Arrangement Involving Other Lenders}

It is possible that a company in financial difficulties will have arrangements with a number of lenders. In such situations, the major relationship lender may present restructuring arrangements to other members of the lenders group and seek support for additional working capital finance, a reduction of outstanding commitments or waiver/deferral of interest.

Such proposals prior to implementation should be subject to the full credit appraisal and approval process and further be subjected to legal scrutiny to ensure the Bank's position is fully protected and that existing security arrangements are unaffected.

\section{K. Monitoring and Control}

Monitoring and control are of primary importance to the management of risk. For the cases fully assimilated in the distressed management team under primary management, monitoring and control shall be carried out by them.

\section{Consideration for Effective Monitoring and Control}

This should be both from internal and external sources. This primarily is through:

\section{1) Internal:}

* Daily excess reports and loans in arrears report;

* Financial History report;

* Other bank account behavior;

* Conditions and Covenants compliance Security monitoring.

2) External:

* Behavioral Customer Information;

* Business Environment Information;

* Plans, budgets and forecasts;

* Management accounts;

* Audited accounts;

* Customer visits.

The strategy for an account should be reviewed frequently and as a minimum quarterly. This primarily is to assess the current strategy and if still appropriate. Any subsequent change in the strategy must be documented with rationale for the change as well as clear timelines for the revised approach and reported appropriately.

\section{OBSERVATIONS/RECOMMENDATIONS}

Proper management of problem accounts has substantial benefits to the bank and customer. These include:-

- A focused risk activity on higher risk customers with the involvement of experienced and dedicated managers who will need to have specific responsibility for the distressed portfolio and need to work in conjunction with Relationship Managers to provide business solutions while avoiding common pitfalls.

- Customer contact that will deliver solutions and corrective strategies direct to the customers.

- Establishing a specialized process will achieve the Bank's key aim of reducing both provisions and eventual losses.

- From a customer perspective, the development of partnerships with businesses in difficulty should increase customer satisfaction through aligning the Lender's/Bank's processes with the customer requirements.

\section{Challenges EXPERIENCED IN Distressed DebT MANAGEMENT}

There are quite a number of challenges both internal and external and the below list is not exhaustive. For this purpose, I have only included some of the internal challenges.

\section{1) Lack of clear reporting lines}

Most lenders have the distressed debt team sit within the larger credit team reporting to credit. Due to this, the 
empowerment guard is lowered and hence this provides a lack of independence. Distressed debt team and is not able to follow through the strategy independently without interference. When a deep dive analysis is done for businesses, some of the causes could be as a result of lack of proper debt structuring as a result of limited information/full disclosure or lack of proper analysis or lack of proper understanding of the business. When these issues are highlighted, blame game may arise which causes a lack of focus on the strategy. The process of remediation may be dragged as a result of wanting to protect one's interest and in the process the strategy is de-valued/delayed/obscured or stalled. The other reason is increased provisioning which most often than not sits with the target of business/function heads. Apart from impairment mitigation there are instances where as a result of deteriorated credit risk, the business needs to make a call to take further provisions and since this is going to affect the bottom line, this may be obscured and hence frustrates the necessary action to be taken by the distressed debt team. As a solution, the debt distressed team should be independent of any credit interferences and should be given empowered mandates/discretions.

\section{2) Business interference}

Relationship team does run with sales targets and is measured on income and growth, when a name goes bad and requires to be downgraded, the strategy to be employed may not necessarily be favorable to their numbers and normally dilutes their income and growth. Because of the negative impact on the balance sheet, they may not be forthright with information and hence frustrates the strategy especially when it touches on Debt Reduction or Managed Exit. Not realizing that when the risk has crystallized it does affect the bank numbers due to impairment risk but since impairment may not affect them directly, they would rather massage the name to protect their interest.

\section{3) Unperfected securities}

This is normally encountered often. When a dispensation is granted for an early drawdown, security perfection is no longer monitored closely/ given priority by the relationship. Due to this, if a name goes bad and securities had not been perfected, recovery action becomes protracted due to securities remediation and chasing documents that may not have been fully signed/executed becomes a difficult task especially in cases where a name moves from the clean book all the way to recovery.

\section{4) Lack of Proper Reporting}

Lack of candidness with the customer trying to protect the relationship does not bear fruits. It is a process in futility. The relationship team most often than not finds it not in their hearts to communicate to the client candidly especially when there are breaches on financial covenants/special conditions. When an account is handed over to the distressed debt team who communicate in a straight line with the customer, the customer finds it hard to comply since they have always been baby sited for lack of a better word. Some of the issues would have been addressed but due to this issue, the customer gets the wrong signals even when they know that they are not doing well since the relationship team was protecting their interest by wrong messaging.

\section{5) Delay in decision making}

This mostly is due to layers involved in the approval process or delay in provision of information by the client or as a result of a delay in the various touch points. This affects business operations in terms of either cash flow in a restructure/funding scenario lost opportunities which may never be salvaged/recovered and hence affect the survival/resuscitation of the business.

\section{6) Lack of Cooperation and full disclosure by the borrower/customer}

This being the key external challenge that is experienced while trying to address the issues of concerns with customers. It becomes a tall order to try and dig for information that may not be forth-coming resulting in drawing a judgement with limited information which may not be the right/full solution in mitigating the failure/issues at hand. Customers should be able to realize that a financial institution or a lender is a partner who has the best interest for their business to succeed. Non-disclosure agreements can be signed to provide comfort to clients to enable them to share information that may deemed confidential.

The triggers for transferring cases to recoveries:

- Where notification is received that a customer has or is about to enter a formal insolvency process, namely Administration, Administrative Receivership (including Agricultural and Book Debt Receiverships), Bankruptcy, Liquidation or Voluntary arrangements.

- Enforcement of security is required.

- Litigation is required to obtain repayment of the debt

- Formal Demand Notice has been issued and acceptable proposals have not been received within a reasonable period (normally one month from the date of demand).

- The customer is unable to meet their liabilities as and when they fall due.

- Notice to re-bank / re-finance has been given but not achieved within 3 months of the request.

- Trading activity has been diverted from the account or the customer has ceased trading affecting the repayment of the debt.

- A voluntary strategy has failed to be achieved within a specific period (normally expected to be within 3 months of the request being made) e.g. sale of assets.

- Debt has been restructured and the revised repayment schedule has broken down.

- Fraud has occurred (only when there is a debtor or guarantor to pursue for recovery of the debt).

- Watch list $2 \& 3$ accounts where exposure is below the distressed debt management (or its equivalent) acceptance criteria, and the Bank's strategy should therefore be managed exit.

This is not an exhaustive list.

Common challenges within Corporate Recoveries:

- Securities-Unperfected securities and other sanction conditions;

- Files-Missing documentation;

- Communication-Failure in sending notices especially breach notifications which delay/protract recovery action;

- Delays in handing over customers after downgrade; 
- Impact on P\& L;

- High loss rates - Impairment;

- Interest and other non-funded income;

- Reputational risk;

- Low /poor customer satisfaction - this translates to low NPS Score;

- Bureaucracy in government agencies; Land offices, Courts, etc.

\section{A. The Commercial Bank Risk Management Framework}

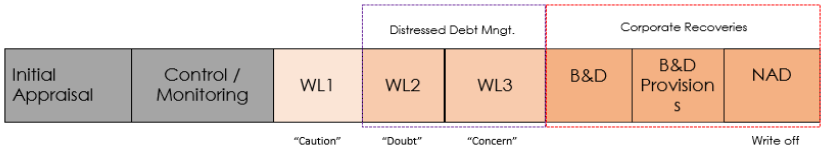

By engaging early, the lender/bank can focus on Turnaround - not only Workout and Recoveries.

\section{B. Robust Credit Process}

\section{Simplified Credit Process}

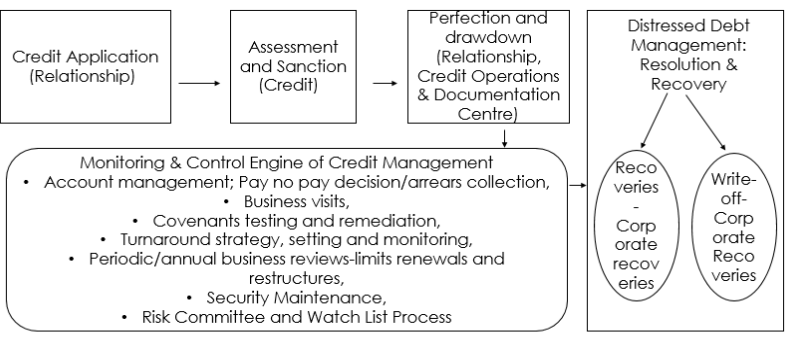

Robust Credit Process

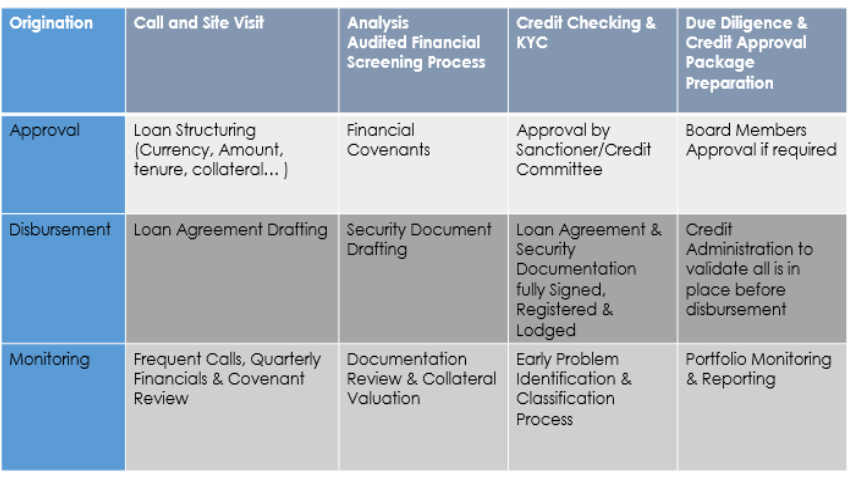

\section{Simplified Credit Process}

The case manager will need to maintain proper care of the customers by ensuring:

- All customer requests are responded to formally \& a copy is maintained in the customer file;

- Proper understanding of respective procedure manual and applicable policies;

- Maintaining a good relationship with customers via (planned and surprise) frequent visits and calls to their business premises;

- Proper understanding of the market the lender is operating in;

- Maintaining customer files fully updated at any given time;

- Early referral of customer issues to credit can be identified in the early waring questionnaire.

\section{Distressed Debt Managers}

This is a high-bird/specialist role since the manager wears a double heart of a credit analyst/manager and a relationship manager at the same time. They are expected to manage very complex transactions, manage very difficult customer's engagements and at the same time offer excellent service to the borrower to ensure that they are no unmet expectations.

Managers in distressed debt management will have to be vetted thoroughly by any lender/recruiter to ensure that they onboard competent individuals who will help the customer to turn around through remediation or resolution to mitigate against credit loss in the distressed book. Below are some of the competences that a prudent lender will be looking for this area of specialty.

\section{E. Technical Skills}

Advanced skills in Risk Management policies and procedures;

- Strong knowledge of business entity legal structures and risk rating;

- Good understanding of financial statements and ratios, credit reports, personal financial statements;

- Excellent report writing and presentation skills;

- Knowledge of respective Central Bank prudential guidelines;

- Excellent analytical and numerical data skills;

- Good knowledge of corporate finance and insolvency law;

- Sound credit analysis;

- Detailed understanding of policies for provisions/ write offs/IFRS9;

- Excellent Relationship Management Skills;

- Proper knowledge of receivership and administration scenarios.

\section{F. Leadership \& Others}

- Decision making -ability;

- Ability to mentor and coach staff to goal definition and achievement;

- Performance Management and team-building skills;

- Excellent interpersonal, communication;

- Influencing and negotiation Skills;

- Excellent Emotional Intelligence;

- Excellent business leadership skills;

- Excellent stakeholder's management skills;

- Excellent planning, coordination and time management;

- Excellent team leadership skills with good team performance management ability;

- Excellent stakeholders management.

\section{LESSONS LEARNT}

\section{A. Specific Lessons Learnt}

1) Credit Process

\section{* Target Market Criteria (TMC)}

Business should only look to on-board clients within the target market criteria as set out within the Lender's risk appetite.

\section{* Call Reports}

Lending requests must be accompanied by a call report, especially where credit issues have been identified for further 
investigation and resolution. These meetings should have the accountable RM and Corporate Credit Manager or equivalent in attendance.

* Business Banking and SME clients with inherent risk

Carry out Enhanced KYC on the promoters of the business as part of the on boarding process.

* Financials and Audited Accounts

Audited accounts must be prepared by auditors on the list of Institute of Certified Public Accountants of Kenya (ICPAK) approved firms which database is updated on an annual basis. The accounts must be in a form acceptable to the bank as stipulated in the facility letters.

* Structuring of Facilities for MANDOC clients

Closed loop structure to be adopted given the track record of diversion risk. Proper structuring of deals through proper business and financial analysis.

\section{* Ownership of Credit applications}

Credit Applications must be reviewed and approved by the accountable RM and Product team staff (where applicable) prior to submission to the country sanctioning/approval team.

\section{* Due Diligence}

Proper due diligence is to be conducted by the Relationship and Credit Teams on any deal that is being on boarded to the bank. There is a need to include the representative from special asset team during deal structure especially in new business committees or equivalent.

* Acceptable Auditors for Significant Exposures

For significant exposures above USD 10M, the acceptable Financials should be from the top 5 Accounting Firms or there should be a condition that requires that on a going forward basis.

\section{2) Approval Process}

\section{* Waivers/Dispensations/Amendments}

Changes to original terms sanctioned under a facility should not be tolerated.

* Timelines for downgrade of accounts

Recommendations for the downgrade of an account from the relationship team should be actioned by the accountable Credit Manager or equivalent within 10 calendar days or less from the decision. This enables the address of risk before it deteriorates. Right messaging to the customer should be set by the relationship team for cohesion and integration of account.

\section{* For Complex and specialised deals}

Engage an expert in the industry of the deal to review and give guidance to avert any uncovered risks that the lender may not be privy to and related concerns around the deal.

* Timelines in approval of Deals

Sanctioners to adhere to the end to end process articulated and challenge to fully understand the structure of a deal if need be.

\section{3) Monitoring and Control}

* Risk Control Unit/Credit operations or equivalent for Credit requests

Country sanctioning team to seek the accountable Risk Control Manager's or equivalent input on a client's general credit risk profile whenever a credit request and/or excess report has been raised.

* Post Sanction fulfillment

All applicable conditions e.g., covenants/internal reporting triggers and drawdown parameters must be clearly reflected in the Facility Letter Aide Memoir. Risk control unit manager or equivalent should be consulted for clarity on wording of conditions. This will minimise data integrity reports and hostilities at post sanction fulfillment stage and hence saves time that would have been wasted in corrections/remediation.

\section{* Transaction Monitoring}

This should be done on a daily basis through the daily risk reports as well as monthly through the Account History report summary to ensure that any anomalies are picked up early. AML system to be properly integrated to raise any flags for any account suspicious activity like cheque kitting that is hard to detect in a manual process.

\section{* Covenant Testing and dealing with Breaches}

Covenants are tested in line with the approved testing frequency (Monthly, Quarterly, Half Yearly and Yearly) Identified breaches should have been investigated and reported to the sanctioning team within 10 days or less.

\section{* Early Warning Questionnaire}

Relationship \& Credit team to run all clients within their respective portfolios through an Early Warning List questionnaire where triggers have been raised and which should be integrated with reports for interim/annual reviews.

\section{* Risk Report Review Meetings}

Risk Control Unit/Equivalent should make use of the available monitoring tools for appropriate action to be taken by the Relationship \& Credit team ahead of the Risk Report Review meeting for objectivity. The meeting should be seen to be achieving traction rather than ticking a checklist.

\section{* Escalation of issues identified}

Any issues raised by the Risk Control Unit or equivalent during the course of business that is not fully addressed by the accountable RM/CCM should be escalated to the country sanctioning team for guidance.

\section{* Monitoring of newly disbursed facilities}

The Monthly Risk report review pack to include a commentary on performance of newly disbursed facilities. This will help with early detection and timely remedial action to be taken.

\section{* Annual Client calls by monitoring unit}

Risk Control Managers/Equivalent must visit clients at least once a year and particularly as part of the client's annual review process. This is recommended with a view to determining the seriousness of the issues arising and for appropriate remedial action to be taken.

\section{* Breach Letters}

All approved breach notification/reservation of rights letters are to be signed by both Relationship and Risk unit/equivalent and issued to the clients within 24 hours of release. An acknowledged copy should be filled in the credit file. In situations of recovery through litigation, documentation is very key and the bank should ensure that all relevant documentation is in place and easily accessible at all time.

\section{* Diversion of Funds for Working Capital facilities}

A robust monitoring system should be employed (benchmarked against highest market standards) to support the monitoring and control activities in relation to working capital facilities, especially on diversion of funds.

* Securitization process

Review of securities for high risk names identified during 
watch list/risk meeting should be initiated and completed to avert any operation risk and identified gaps in the documentation remediated and closed immediately by the relevant unit. In situations where the names are downgraded from normal book to recoveries hence addressing security defects should be a priority especially for high risk names under watch list.

\section{* Collateral Type}

Security must be thoroughly scrutinised to ascertain ownership, enforceability and recoverability by the Risk Control Unit or its equivalent in conjunction with legal team. Security appetite to be set appropriately especially for upcountry collateral, plant and machinery and specialised equipment. For parental guarantee and cross border security, legal team should provide guidance. Through experience, some of the cross border parental or otherwise guarantees seen not enforceable

* Timely Actioning of Issues

Credit Manager must attend to all issues raised by Risk Control unit/committees or agreed remedial actions in a timely manner e.g., covenant breaches, unsatisfactory account conduct, outstanding security issues, etc. for appropriate remedial action to be taken by the Bank.

\section{* Updated Strategy sheets}

Strategy sheets must be updated by the accountable Credit and Relationship Manager and captures not historical information but current information touching on business operations, debt status, financials, and client strategy.

4) People; Credit, Risk Control unit/Credit Operations or Equivalent, Distressed Debt Managers or Equivalent, Relationship Team

\section{* Training \& Induction Gap}

There is a need for a thorough induction/training program around Product Knowledge, Lending Process, M\&C activities to enable new joiners (Relationship Mangers and their Assistants) to perform their roles effectively.

* Business Continuity Management (BCM)

There is a need for proactive BCM structure by the business team leadership as M\&C activity is impacted whenever a Relationship Manager goes on leave.

* Role of Risk Control Unit (RCU) or Its Equivalent

RMs to recognise the importance of RCU/equivalent and attend to all issues raised and follow up on agreed remedial actions in a timely manner e.g., covenant breaches, unsatisfactory account conduct, outstanding security issues, etc.

\section{* Support from Leadership}

Consistent and firm support to the Credit Team especially where issues have been escalated to them. There should be clear punitive corrective action taken on repeat offenders (internal $\&$ external) to drive the right behaviour among the team members.

\section{* Communication}

To be clear and transparent in all communications and dealings with customers and stakeholders. Challenge things you believe to be wrong and be open to challenge from others. Take feedback constructively.

\section{* Market Intelligence on clients}

Credit team should conduct market intelligence checks with their networks in the other financial institutions in the market to ascertain how the multi banked clients are performing elsewhere.

\section{* Consequence Management}

Country Sanctioning Team in collaboration with Coverage heads to take appropriate corrective action on the culpable staff where staff conduct is unbecoming and impacting the credit risk management process.

\section{* Escalation of issues}

Material non-public client information that could have a negative impact on client's financial and credit risk profile should be escalated to Head of Credit or Business Segment Head for timely but appropriate remedial action to be taken.

\section{* Lessons Learnt}

Presentations for watch list and impaired debt transactions should be conducted in partnership with the accountable origination and/or sanctioning team members. Lessons learnt from other territories to be shared with the credit and coverage teams.

\section{* Collaboration}

Staff to engage and build synergies amongst themselves and avoid working in silos to achieve shared growth and common objectives.

\section{* Resource}

People agenda to be addressed in respect to head count, portfolio size, skills, and desired outcome.

* Timely actioning of Issues

Accounts flagged by Risk Control Unit or its Equivalent as showing adverse account features to be actioned in a timely manner to avoid situations where accounts are moved from Clean to Watch List 2/3/Recovery.

\section{5) People; Governance \& Control, Operations Risk}

\section{* Identification of Risk}

Support the business to avert any operational risk and provide guidance to the business.

\section{B. General Lessons Learnt}

* Overreliance on one key Director-Owner of businessEnsure to take Key man insurance and motivate the customer to do so since it id for mutual benefit.

* Perform though due diligence for any take overs.

* When calculating the $\%$ of financing for vehicle under re-finance, consider the age of the vehicle and asset model type.

* Confirm reliability of contracts \& assignments of receivables where applicable while assessing repayment source.

* For refinancing, consider doing valuation/assets assessment to inform the decision process.

* Confirm tracking is installed and close monitoring is in place \& availability of tracking reports.

* Consider obtaining a buy back guarantee from the supplier for specialized equipment/s.

* For any waivers granted, full mitigation on the risks to be evidenced especially on large fleet financing.

* Consider obtaining hedging swaps for LC's which are converted to loans to protect against Forex fluctuation.

* Maintain a schedule of the assets for close monitoring.

* Thorough review of the account conduct via inflows.

* Expert share on ABF emerging issues and impact on portfolio.

* Frequent monitoring of receivables, account inflows and existing contracts to ascertain any changes in 
funding requirement especially for invoice discounting or STLs (Short term loans/Stock loans, etc.).

* Regular sharing of the emerging issues in the industry which will inform the appetite.

* Assess reputation risk for government and county projects during deal structure.

* Where a lending is against receivables from a specific contract, there is still a need to evaluate the customer's business so as to build safety nets in case the contract has issues down the road.

* Proper feasibility to be done on new motor vehicle models in the market to ascertain their reliability and likely resale value.

* A deep dive on securities issues to be conducted more especially where there is security sharing and or are supposed to share such securities.

* Receivables from contracts from which loan repayments will come should be more visible and ringfenced.

* Use of a Buy Back Guarantee to be considered for ABF facilities especially for Chinese Models, selling them after repossession is a tall order.

* Not having a debenture on the customer's assets denies a chance to appoint a Receiver/Administrator and get a better view of the business once the debt is c called up. (New Insolvency Act of 2015).

* Due diligence is required for multi-banked customers, the borrower may be having other facilities with other lenders which are not disclosed and not detectable in the financial statements or in CRB reports.

* For invoice discount facility, Invoices needs to be called-back and or tracked to:

- Confirm authenticity and not from related parties/businesses;

- To check that none has been paid or discounted previously Customer may present invoices already paid/discounted.

* Invoice discounting facilities should not be done at $100 \%$. This at the very least will ensure that the facility interest charges have been catered for and tax element excluded.

* Analysis of account operations and repayments of maturing contracts it's prudent that a thorough account review through statement analysis and Account History Report is always done at every review.

* STL facilities proceeds need to be paid directly to the supplier.

* Receivables against invoice discounting should be formally assigned to the lender and maturity period of facilities to be in sync with receivables receipt period. To be guided by invoice dates and trade terms.

* For Invoice Discount facility, robust monitoring of business proceeds against maturing invoices before drawdown of new facilities is highly recommended; you may find drawdown done to clear excesses occasioned by matured facilities.

* Ensure to monitor Special conditions especially in cases of staggered payment for short term loan facilities.

* Proper analysis should be done for every business, avoid name lending, media hype lending, etc.
* Consider not to use Biological assets for lending due to vulnerabilities - death, diseases, highly mobile, re-sale etc.

* Typically, independent feasibility studies requires to be provided as part of assessment for start-ups by subject matter experts and not the borrower.

* Review appetite on start-ups going forward to capture the learnings from this case.

* Take into account a balanced mix of market covering both direct and auction when dealing with floriculture business and related risks.

* Involve services of subject matter experts for their professional advice when seeking to support new customers who are dealing on specialized lines.

* For start-ups, Impairment test using Stage 3 impairment assumption is to be run as part of the reviews to inform any mitigations needed in cases of stress.

\section{STRATEGIES FOR DistRESSED DEBT MANAGEMENT}

\section{Portfolio Deep dive}

- Existing Remedial \& Recoveries Portfolio;

- Potential Remedial \& Recoveries book (in Normal \& Watch status);

- Early intervention.

Sector Split of Portfolio

- Corporate, SME/Business \& Retail;

- Strategize to employ different strategies per sector;

- Set up/Utilise/Improve on existing teams to handle the various portfolios;

- Establish/review Remedial \& Recoveries Procedures.

Early Identification for Timely Remediation

- Early Identification, Early involvement, Early Watch Questionnaire, Early Watch Committee;

- Market and industry Intelligence based Take Overs.

Exploration of Alternative Remedial/Recoveries Strategies

- Business visits is key;

- Negotiate/Settle as much as possible;

- Unconventional strategies: JV's, Equity/Capital Investors, Take overs, Receivership Administrations scenarios (Insolvency Act), Private Treaty Sale Adverts.

\section{Team Strategies}

- Recruit right, reap bountifully;

- Skilled capacity: Credit, Analysis \& Negotiations training, Understanding businesses, Relationship / Recoveries exposure;

- Empower, Expose, Appreciate \& Motivate team members;

- SMART Objectives \& Regular monitoring/engagements

- SMART Targets: Budget, Quarterly/Mid-Year Review, Reward Appropriately;

- Team Strategy/Experience sharing sessions.

Customer based vs Portfolio based Strategies for Corporate names

- Credit analysis, Financial Analysis, Business understanding, Management, Industry; 
- Root cause analysis;

- Remedial options - Restructure, Re-banking, JV's, Capital/Equity Injection, Administration, Settlement, Recoveries - Sale of Assets, Investor funds, etc.

- Inter-lenders common approach engagements.

For SME/Business \& Retail Names

- Portfolio Management;

- Daily Dashboard Monitoring;

- Reward based efforts, Outsourcing and Debt Sale.

Professionals Partnerships

- Independent Business Reviews, Monitoring Agents, Business Advisory Services, legal firms, Industry specialists.

\section{Stakeholder Management}

- Regular engagement/feedback to Business;

- Align on Strategy \& involve for influence;

- Joint review - problem accounts;

- Credit/Impairment Committees \& Board Credit committee.

\section{Credit Feedback Mechanism}

- Review Bank Credit Policy/ Classification policies;

- Inform/contribute to bank processes/policies on problem accounts.

\section{Sharing of Lessons Learnt}

- Share lessons learnt from Remedial/Recoveries names;

- What can be done differently?

- Inform credit policies;

- Proactive as opposed to reactive management.

\section{ACKNOWLEDGMENT}

I acknowledge all the cases that I have managed whose experience has born this paper. I also acknowledge all the stakeholders I have interacted with in this journey. Special appreciations to all my superiors that have been of tremendous help in management of cases and have shaped my career,Paul Asamba, Eric Sila, Anne Mbatha \& Ken Kiurah.

\section{REFERENCES}

CRB Regulations Act of 2015.

https://www.centralbank.go.ke/wpcontent/uploads/2021/05/Credit-

Reference-Bureau-Regulations-2020.pdf.

CBK Prudentail Guidelines. https://www.centralbank.go.ke/policyprocedures/legislation-and-guidelines/prudential-guidelines/.

Dairies. Industry/Sector analysis \& Micro-economic Updates.

Economic Forums.

Gained experience. Origination, Approval, Disbursement and Monitoring; through end to end case management over the years.

Insolvency Act of 2015.

http://kenyalaw.org/k1/fileadmin/pdfdownloads/Acts/Insolvency_Act18of20

15 _-_compressed.pdf.

IFRS9Impairment Accounting Standard.

https://www.iasplus.com/en/standards/ifrs/ifrs 9

Market Intelligence.

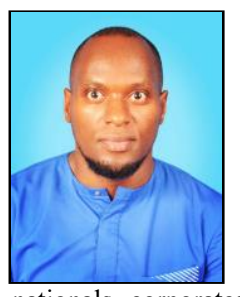

Robert Muriithi is Seasoned banker with over 10 years' experience in the banking industry in Deal Origination, Approval, Disbursement \& Monitoring.

He is currently a Director in the Board of a Private Capital Firm which is Actively Acquiring in the Manufacturing Industry and also a Senior Manager in Credit Risk Advisory Group in a Tier one Bank in Kenya and manages a blended portfolio of multinationals, corporates and SME's under Credit Risk Advisory Group a department under Credit Risk Management Function. He is experienced in performing Robust Credit Quality Assurance programs that ensures sound quality in the credit portfolio through effective monitoring and review of the credit environment, processes and related developments, and ensuring compliance with policies and approval terms and conditions throughout the life of the credit facility by providing direction, leadership and advisory.

Among many other skills acquired, his key skills being, Relationship Management, Credit and Financial Analysis, Service Excellence and Strategy Formulation. Detailed understanding of policies for provisions/ write offs/IFRS9, with in-depth experience in Debt Re-structuring, Management of very complex and syndicated debts, diversified cases and cross-border transactions with a track record of generating competitive returns whilst minimizing related attendant and inherent risks embedded in the cases. Well versed with corporate finance and Insolvency law and experienced in administration and liquidation scenarios of syndicated debts.

Dynamic Business Leader who effectively communicates direction with a strong practical approach, strong team leader and facilitator with natural ability to identify business opportunities and encourage collaborative approach with proactive attitude and passion for envisioning a successful outcome or results.

Robert has a Master of Business Administration-Strategic Management \& Finance Option from the Jomo Kenyatta University of Agriculture \& Technology and a Bachelor's Degree in Mathematics and Computer Science from the same university. He has other professional trainings from other institutions and also hundreds of in-house trainings. 